Bryn Mawr College

Scholarship, Research, and Creative Work at Bryn Mawr

College

Anthropology Faculty Research and Scholarship

Anthropology

1980

\title{
On the Central Asian Paleolithic: Reply to Recent Comments
}

Richard S. Davis

Bryn MawrCollege, rdavis@brynmawr.edu

V.A. Ranov

Let us know how access to this document benefits you.

Follow this and additional works at: http://repository.brynmawr.edu/anth_pubs

Part of the Anthropology Commons

\section{Citation}

Davis, Richard S. and Vadim A. Ranov. "On the Central Asian Paleolithic: Reply to Recent Comments." Current Anthropology 21, no. 6 (1980): 809-810.

This paper is posted at Scholarship, Research, and Creative Work at Bryn Mawr College. http://repository.brynmawr.edu/anth_pubs/6

For more information, please contact repository@brynmawr.edu. 
Oszipowa, E. W. 1977. Socjologija Emilja Durkheima. Moscow: Nauka.

SkAZKIN, S. D. 1976. Der Bauer in Westeuropa während der Epoche des Feudalismus. Berlin: Akademie.

Tarkowska, ElzBIETa. 1974. Durkheim, Mauss, Lévi-Strauss: Ciaglosc $i$ zmiana socjologii francuskiej. Warszawa: PWN.

WALlERSTEIN, IMMANUEL. 1974. The modern world system: Capitalist agriculture and the origin of the European world-economy in the sixteenth century. New York: Academic Press.

Wladyka, Maria. 1974. Teoria faktu spolecznego w systemie socjologicznym Emila Durkheima. Wrocław/Warszawa/Kraków: Ossolineum.

Zaszlavszkaja, Tatjana. 1977. Metodologicheskiye problemy sistemnovo izucheniya djerevnii. Novosibirsk.

\section{On the Central Asian Paleolithic: Reply to Recent Comments}

\section{by Richard S. Davis and Vadim A. Ranov Bryn Mawr College, Bryn Mawr, Pa. 19010, U.S.A./Institute of History, 33 Lenin Prospekt, Dushanbe 734025, U.S.S.R. 15 VII 80}

Yeritsian (CA 20:603-4) is well acquainted with Central Asian Paleolithic archaeology by firsthand experience, but nevertheless he has made several very questionable interpretations of the evidence. His use of the Russian geographical term "Tsentralnaya" (Central) Asia to refer to "Srednyaya" (Middle) Asia is incorrect. Much more important, however, is his challenge to our basic periodization and chronology. Basically, his thesis is that the Central Asian Paleolithic was distinctly different from that of either southwestern Asia or Europe and that developments in Central Asia lagged considerably behind those in the other two areas.

For example, Yeritsian maintains that the Lower Paleolithic of Central Asia is not typologically distinguishable enough from the Middle Paleolithic "to identify it as a distinct epoch equivalent to the Acheulian of Europe." Technologically and typologically, however, the Lower Paleolithic stone tools from Karatau and Lakhuti are quite distinguishable from those of such Middle Paleolithic sites as Teshik Tash, Obi-Rakhmat, Dzhar Kutan, and many others. More specifically, Central Asian Middle Paleolithic sites commonly have Mousterian points, a variety of sidescrapers, some Upper Paleolithic elements, and blades, but practically none of these major categories are found in the Lower Paleolithic loess sites. Even if this distinction didn't exist, however, why must Yeritsian look to Europe for the standards for Paleolithic epochs? There the differences between many Upper Acheulean sites and subsequent Mousterian ones are often subtle indeed, as there is considerable overlap in technology and typology between them.

Yeritsian also believes that the Lower Paleolithic material of Central Asia can all be assigned to the Upper Pleistocene. $\mathrm{He}$ neglects, however, to give reasons for this conclusion. He remarks that the cultural materials were found in "geological outcrops" and not true cultural layers, but we can only point out that the extent to which the lithics have been redeposited only indicates a greater antiquity for the artifacts than for their surrounding loess matrix. Stratigraphically and chronologically the Lower Paleolithic is well separated from the Middle Paleolithic, as we made clear. The combination of thermoluminescence dating, stratigraphic position in the sixth buried soil complex, and the paleomagnetic data makes it virtually certain that the artifacts from Karatau 1 are Middle Pleistocene (preLast Interglacial) in age.

While it is true that the dating of the Middle Paleolithic of Central Asia is not well established, there is certainly no basis for supposing that all or most of it comes from the second half of the Würm as Yeritsian seems to imply. First of all, the $\mathrm{C}^{14}$ determination at Ogzi-Kichik is not reliable; it was made on a sample of charcoal dust. Hence, this determination can in no way be used to make it "quite definitely established" that the Middle Paleolithic can be dated to the second half of the Würm. Secondly, the fauna from the Middle Paleolithic cave sites is certainly compatible with an early-Würm date.
As for Yeritsian's belief that the Central Asian Upper Paleolithic didn't get under way until the end of the Pleistocene, we can only point out that Layer 3 at Kara Kamar, northern Afghanistan, is definitely Upper Paleolithic in the commonly accepted meaning of the term and is reliably dated to more than 32,000 years B.P. Also, Shugnou in Tadzhikistan clearly dates to a time before the end of the Pleistocene.

The use of the term "Mousterian" to describe some Middle Paleolithic industries in Central Asia is a delicate issue, and Yeritsian finds our application of the term objectionable because "none of [the sites called Mousterian] contain a set of tools characteristic of only one epoch." This to us is no argument, because it is clearly the case in southwestern Asia and in Europe that industries described as Mousterian have both Lower and Upper Paleolithic elements. The use of the term "Middle Paleolithic" makes perhaps fewer assumptions, but if industries in Central Asia bear a relatively close resemblance to Mousterian ones farther west, why not call them Mousterian? This is certainly what Movius (1953) and Bordes (1968) have done for Teshik Tash and other Central Asian sites. Our use of the term was meant to convey the sense of a widespread technological/ typological complex found in many parts of the Old World and generally dated to the first half of the Würm. The identification of specific "cultures" or "ethnic affinities" in various Central Asian Middle Paleolithic stone tool collections is very difficult, and we have never attempted it. Yeritsian has apparently misread us on this point; we clearly stated (p. 256) that the variants of the Mousterian in Central Asia are not "representative of separate cultural groups."

In sum, Yeritsian attempts to portray Central Asia as a refuge for survivals of cultural developments elsewhere. He even suggests ("It is symptomatic...") that a lower amplitude of climatic fluctuations during the Central Asian Pleistocene may have been partially responsible. We do not find any compelling evidence to support his position.

We welcome Kolb's comments (CA 21:30-31). It simply was outside the scope of our paper to integrate the northern Afghan Paleolithic materials with those of Soviet Central Asia. To some extent, this had already been done by both of us previously (Davis 1974, 1978; Nikonov and Ranov 1973). In this context it should be made clear that Kara Kamar Layer 3 is genuinely Upper Paleolithic, but the Kuprukian (A or B) is best described as Epi-Paleolithic. There is no basis for dating the Kuprukian any earlier than 14,000 B.c. as Kolb does. Neither the Kuprukian nor Kara Kamar has close analogies in Soviet Central Asia.

The most striking similarities which do exist between the two areas are found in the Mesolithic. Vinogradov (1979) has recently published the results of surface surveys he conducted between Andkhoy and Tashqurghan in the area where the desert sands which flank the Amu Darya meet the alluvium brought down by rivers from the Hindu Kush. Here he has found more than 100 sites rich in microblades and geometric microliths. Vinogradov has noted, and we agree, that his Mesolithic sites in many respects resemble the lower layer at Dam Dam Cheshme 1 and the fourth ("upper") layer at Dam Dam Cheshme 2 in the eastern Caspian region. Close similarities are also found at Tutkaul Layer 2a in Tadzhikistan.

Kolb points to some problems associated with the thermoluminescence dating of loess sediments; this is a point which 
must be qualified. Recent evaluation of this technique indicates that it offers good relative and lateral consistency when it is applied to related stratigraphic sections, but the absolute dates tend to be too recent, particularly as the samples increase in age (Dreimanis et al. 1978:57). As we pointed out, it is the convergence of several lines of evidence (stratigraphic, paleomagnetic, and thermoluminescence) which allows a good measure of confidence in the dates we presented.

With regard to the issue of pebble tools in the late Paleolithic and Neolithic, what is quite remarkable is that between the Mesolithic and the Hissar Neolithic there is an abrupt change in tool inventory, the latter showing a very high frequency of pebble tools. This kind of transition is not, however, characteristic of the change from the Caspian Mesolithic to the Dzheitun Neolithic, where there is much greater continuity in stone tool technology.

The nature of the Lower Paleolithic in Kazakhstan is not well known. Alpysbaev (1979) has recently reviewed the subject in a book-length monograph. The stratigraphic picture and the dating of these bifacial industries are still not well developed.

Rolland (CA 21:378-80) is quite correct that there are many bifacial tools east of the Euphrates, and we have certainly been aware of this fact for some time. What we left out of our sentence was "and west of the Indus." We did refer twice to the bifacial industries of Kazakhstan.

Rolland presents several alternative possibilities for Middle Paleolithic culture history in Asia. As he is well aware, there simply are insufficient data available to resolve this complex topic, and we will probably have to pursue somewhat more modest objectives for some time to come.

\section{References Cited}

Alpysbaev, Кн. A. 1979. Pamyatniki nizhnego paleolita yuzhnogo Kazakhstana (Monuments of the Lower Paleolithic of southern Kazakhstan). Alma-Ata: Nauka.

Bordes, Françors. 1968. The Old Stone Age. New York: McGrawHill.

Davis, R. S. 1974. The late Paleolithic of northern Afghanistan. Unpublished Ph.D. dissertation, Columbia University, New York, N.Y.

- 1978. "The Palaeolithic," in The archaeology of Afghanistan. Edited by F. R. Allchin and N. Hammond, pp. 37-70. London: Academic Press.

Dreimanis, Aleksis, et al. 1978. Dating methods of Pleistocene deposits and their problems. 1. Thermoluminescence dating. Geoscience Canada 5:55-60.

Movius, H. L., JR. 1953. Paleolithic and Mesolithic sites in Soviet Central Asia. Proceedings of the American Philosophical Society 97:383-421.

Nikonov, A. A., and V. A. Ranov. 1973. Novyye dannyye ob arkheologii kamennogo veka i vozraste rechnykh terrac AfganoTadzhikskoy depressii (severnyy Afganistan, yuzhnyy Tadzhikistan) (New data on Stone Age archaeology and the age of river terraces of the Afghan-Tadzhik depression [northern Afghanistan, southern Tadzhikistan]). Byulleten' Komissii po Izucheniyu Chetvertichnogo Perioda 40:35-51.

VinogRADOv, A. V. 1979. Issledovaniya pamyatnikov kamennogo veka v severnom Afganistane (Investigations of Stone Age sites in northern Afghanistan). Drevnyaya Baktriya 2:7-62.

\section{On Obsidian Supply at Colha, Belize ${ }^{1}$}

\author{
by Thomas R. Hester and Harry J. Shafer \\ Center for Archaeological Research, University of Texas at San \\ Antonio, San Antonio 78285/Department of Anthropology, \\ Texas $A$ \& $M$ University, College Station, Tex. 77843, U.S.A. \\ $16 \mathrm{v} 80$
}

Sidrys (CA 20:594-97) has presented certain hypotheses regarding obsidian supply and demand and the production strategies of Classic Maya obsidian industries. We wish to offer a correction of certain of the data on which his study is based and to provide additional information critical to his interpretations.

In Sidrys's table 1 (p. 596), the lowland Maya site of Colha (Belize) appears as Number 28, with 69 obsidian blades attributed to Postclassic occupations. In the absence of trace-element data, Sidrys estimates the "nearest major obsidian source" to be El Chayal, at a linear distance of $406 \mathrm{~km}$. We have now completed two seasons (1979 and 1980) of extensive excavations at Colha (Hester 1979, Hester et al. 1979). The site has a temporal range from Early Preclassic (or early Middle Preclassic) to Early Postclassic. The major function of the site in Late Preclassic, Late Classic, and Early Postclassic times was the production of several kinds of chert (flint) tools, manufactured in massive quantities, much of which was apparently intended for export. Obsidian artifacts, especially blade fragments, occur throughout the cultural sequence. They are infrequent in the Preclassic but are found in some numbers in Late Classic (with Tepeu 2-3 ceramics) and Early Postclassic deposits. One excavation area opened during the 1980 season provides evidence of a small obsidian workshop (of Late Classic date) where this imported material was modified by local knappers.

With these data as a background, there are several points to be made regarding Sidry's use of Colha obsidian data. First, it

\footnotetext{
1 We thank Giancarlo Ligabue (Centro Studi e Ricerche Ligabue) and Helen Michel and Frank Asaro (Lawrence Berkeley Laboratory) for their assistance in the obsidian studies.
}

cannot be assumed that all of the 69 specimens he tabulates are Postclassic in age, as obsidian occurs in various temporal contexts at the site. We do not know the nature of Sidrys's sample, though we presume it is a surface collection. Even so, much of the surface obsidian at Colha occurs on exposed Late Classic middens. Secondly, El Chayal is not the source of Colha obsidian despite its being the "nearest major source." The traceelement composition of 14 obsidian blade fragments from the 1979 excavations was analyzed by Helen Michel and Frank Asaro at the Lawrence Berkeley Laboratory, University of California, Berkeley. Rapid-scan X-ray fluorescence analysis for the elements $\mathrm{Rb} / \mathrm{Zr}, \mathrm{Sr} / \mathrm{Zr}$, and $\mathrm{Mn}$ was used in these studies. Of these specimens, 13 are from Ixtepeque and 1 is from San Martín Jilotepeque (see Stross et al. 1976). The Ixtepeque materials are from Late Preclassic, Late Classic, and Early Postclassic deposits; the San Martín Jilotepeque artifact is of apparent Late Preclassic provenience. Two obsidian blades, of Late Classic (Tepeu 3) age, from the Northern River Lagoon site, $19 \mathrm{~km}$ southeast of Colha, were analyzed by Michel and also found to originate from the Ixtepeque source.

It would seem that El Chayal did not figure significantly in obsidian trade at Colha. This assumption will be tested by further trace-element analyses during 1980. What is important in assessing obsidian distribution is not only the distance between source and site, but also which source is most accessible. In this case it is Ixtepeque, from which obsidian could be distrik... uted by sea and short overland (or riverine) routes. Other factors, such as regional commercial control by certain sites, the presence of trading or redistribution ports along the Caribbean coast of Belize, and use of alternative materials must also be considered. Hammond (1976) has presented a model for Maya trade on the coast of Belize which discusses this situation further. Ixtepeque could have supplied Colha via a trade route roughly $575 \mathrm{~km}$ long utilizing the Motagua River and the east coast up to the Northern River Lagoon and then various other rivers.

Use of alternative materials for blade production in certain lowland regions could have diminished the demand for obsidian. Recent excavations at Colha have yielded extensive evidence of 